\title{
Efek Sosial Psikologis Sistem Zonasi Penerimaan Siswa Baru di SMK
}

\author{
Reni Oktaviana Cahyanti ${ }^{1}$ \\ Fakultas Psikologi Universitas 17 Agustus 1945 Surabaya \\ renioktavia_s2@untag-sby.ac.id \\ Suryanto $^{2}$ \\ Fakultas Psikologi Universitas Airlangga Surabaya \\ suryanto@psikologi.unailr.ac.id \\ Niken Titi Pratitis ${ }^{3}$ \\ Fakultas Psikologi Universitas 17 Agustus 1945 Surabaya \\ nikenpratiti@untag-sby.ac.id
}

\begin{abstract}
This case study research has the aim of describing psychological reactions and psychological social impacts of the zoning system for new student admissions in SMK, using a qualitative approach. The research data were obtained from interviews with a class $X$ SMK student in Surabaya (who experienced a zoning system when accepting new students), parents, teachers and community leaders (the head of the RT where the students live). The results of the interview showed that the subjects of this study did not agree with the zoning system in new student admissions because the zoning system limited the students who excelled to enter their favorite or desired schools, felt disappointed because with the zoning some parties felt disadvantaged because they had spent time to take lessons and have spent money to get into a favorite school and that has an impact on every individual affected by the zoning system. In conclusion, the zoning system has a psychological effect on individuals because it makes them disappointed and reduces the desire to achieve each individual.
\end{abstract}

Keywords: Psychological Social, Zoning System

\begin{abstract}
Abstrak
Penelitian studi kasus ini memiliki tujuan mendeskripsikan reaksi psikologis dan dampak sosial psikologis sistem zonasi penerimaan siswa baru di SMK, dengan menggunakan pendekatan kualitatif. Data penelitian diperoleh dari wawancara terhadap seorang siswa kelas X SMK di Surabaya (yang mengalami sistem zonasi saat penerimaan siswa baru), orang tua, guru dan tokoh masyarakat (ketua RT tempat siswa tinggal). Hasil wawancara menunjukkan bahwa subjek penelitian ini tidak setuju adanya sistem zonasi dalam penerimaan siswa baru dikarenakan dengan adanya sistem zonasi membatasi siswa-siswi yang berprestasi untuk masuk ke sekolah yang favorit atau yang diingankan, merasa kecewa karena dengan
\end{abstract}


adanya zonasi beberapa pihak merasa dirugikan karena sudah meluangkan waktu untuk mengikuti les dan sudah mengeluarkan biaya supaya bisa masuk ke sekolah favorit dan itu berdampak untuk setiap individu yang terkena sistem zonasi. Kesimpulannya sistem zonasi memberikan efek psikologis pada individu karena membuat kecewa dan mengurangi keinginan untuk berprestasi setiap individu.

Kata kunci: Sosial Pikologis, Sistem Zonasi

\section{PENDAHULUAN}

Pendidikan termasuk salah satu aspek penting dalam meningkatkan kualitas sumber daya manusia. Melalui pendidikan yang baik setiap manusia dapat mengembangkan potensi dirinya. Pendidikan merupakan kebutuhan setiap manusia. Pendidikan selalu mengalami perubahan, perbaikan dan perkembangan sesuai dengan perkembangan disegala bidang kehidupan. Perubahan dan perbaikan dalam bidang pendidikan meliputi berbagai komponen yang terlibat di dalamnya baik itu pelaksanaan pendidikan di lapangan, mutu pendidikan, perangkat kurikulum, sarana dan prasarana pendidikan dan mutu manajemen pendidikan termasuk dalam metode dan strategi pembelajaran yang lebih inovatif. Upaya perubahan dan perbaikan tersebut bertujuan menjadikan kualitas pendidikan Indonesia menjadi lebih baik, namun setiap perubahan akan memberikan dampak bagi yang menjalani (Indriana, 2011).

Qian Tang (2016) menjelaskan bahwa selama ini pemerintah Indonesia terlalu berfokus pada angka kelulusan siswa dalam mengemban pendidikan, namun pemerataan mutu pendidikan masih belum menjadi prioritas pemerintah padahal, peningkatan angka partisipasi siswa bersekolah tidak anak berdampak pada pertumbuhan ekonomi nasional siswa tidak mendapatkan kualitas belajar yang memadai. Upaya dalam peningkatan dan pemerataan kualitas untuk pendidikan di Indonesia adalah dengan mengaplikasikan system zonasi pada Penerimaan Peserta Didik Baru (PPDB). Permendikbud menjelaskan PPDB pada Nomor 17 Tahun 2017 memiliki tujuan untuk menjamin penerimaan peserta didik baru akan berjalan dengan objektif, akuntabel, transparan dan tidak adanya diskriminasi supaya mendorong peningkatan akses pada layanan pendidikan. Sistem zonasi merupakan sistem yang memberlakukan dengan penggunaan zona oleh pemerintah daerah masing-masing yang memiliki kewajiban menerima calon peserta didik yang bertempat pada radius terdekat dari sekolah dengan presentase tertentu yang telah ditetapkan dari total jumlah peserta didik yang diterima. 
Penerimaan Peserta Didik Baru (PPDB) pada tahun 2019 sekolah-sekolah masih menggunakan sistem jalur zonasi, sebagai mana yang telah ditetapkan dalam permendikbud No. 51/2018 tentang penerimaan peserta didik baru tahun ajaran 2019/2020. Sistem zonasi untuk calon peserta didik diharuskan untuk menempuh pendidikan di sekolah yang memiliki jarak terdekat dari tempat tinggal masing-masing. Peserta didik memiliki pilihan lain maksimal 3 sekolah dengan syarat sekolah tersebut memiliki kuota siswa dan berada dalam wilayah zonasi yang akan dipilih. Pada umumnya jalur zonasi memiliki kuota sangat besar dari semua jalur penerimaan siswa baru. Sistem seleksi PPDB dilakukan dengan cara pemerintah untuk jalur zonasi dilakukan dengan jarak, nilai UN dan usia peserta didik dan waktu mendaftar (Azis, Djono \& Purwanta, 2019).

Ridhoi (2017) mengatakan bahwa perubahan sistem PPDB dari rangking menjadi zonasi ternyata tidak mengurangi perdebatan yang muncul. Sejak tahun 2017, pemerintah melalui kementrian (kemendikbud) telah mengubah sistem PPDB dilakukan berdasarkan sistem zonasi alih-alih rangking, dengan adanya sistem ini banyak orangtua dan siswa yang mendapatkan dampak dari sistem zonasi yang telah dilakukan terlebih lagi dampak tersebut akan berpengaruh sama psikologis anak yang tidak bisa masuk di sekolah pilihannya, karena adanya PPDB dengan zonasi ini menyebabkan siswa dan orangtua mengalami kekecewaan.

Siswa SMK memiliki kemampuan tinggi dalam kejuruan, memiliki fasilitas yang memadai dan sistem belajar yang mapan karena lebih banyak ke praktik langsung dari pada teori sehingga akan banyak dampak yang di dapatkan dari adanya sistem zonasi yang diterapkan dalam PPDB, sehingga peneliti akan meneliti pada siswa SMK, ingin meneliti efek bagi siswa SMK ketika PPDB menggunakan sistem zonasi.

\section{a. Sistem Zonasi}

Sistem zonasi mengakibatkan peserta didik yang memiliki kemampuan beragam dalam satu wilayah sekolah, bahkan satu kelas. individu yang tidak berprestasi dan individu yang berprestasi dapat menjadi satu tempat. Hal ini akan memberikan pengaruh pada proses pembelajaran peserta didik. Prestasi peserta didik tidak hanya bergantung pada dirinya saja, akan tetapi lingkungan juga menjadi pembelajaran. Rimm (HooverSchultz, 2005) menjelaskan bahwa peserta didik dapat mengalami kurang berprestasi (underachievement), yaitu ketimpangan antara performa akademik di sekolah dan indeks kemampuan individu. Jika individu tidak menggunakan kemampuannya di sekolah, maka individu akan menjadi kurang berprestasi. Kurang berprestasi merupakan salah satu dari masalah kesulitan belajar, selain 
learning disorder; learning disfunction; slow learner, dan learning disabilities. Gallagher (1991) dan Rimm (HooverSchultz, 2005), menemukan ada dua faktor yang menjadi penyebab kurang prestasi ini yaitu, faktor lingkungan (sekolah) dan faktor personal (keluarga). Faktorfaktor lingkungan berasal dari sekolah dan teman sebaya. Sekolah yang tidak mendukung iklim intelektual, berfokus pada atletik dan status sosial semata dapat berkontribusi pada kurang prestasi Rimm (HooverSchultz, 2005). Pengaruh rekan sebaya juga menjadi hal kuat yang memaksa peserta didik potensial menjadi terhalangi prestasinya (Reis \& McCoach, 2000). Bernd (1999) mengutip sebuah penelitian yang mengukur nilai dan perilaku peserta didik menemukan bahwa murid semakin mirip dengan teman sebayanya pada akhir tahun ajaran, dibandingkan saat pertama kali peserta didik masuk sekolah. individu yang memiliki prestasi cenderung akan menurun prestasinya ketika berteman dengan individu yang berprestasi buruk. Sehingga untuk mendukung prestasi peserta didik, maka faktor lingkungan dan faktor personal yang telah dipaparkan dapat dikelola dengan baik.

Menurut Andina (2019), berbagai kendala dalam pelaksanaan zonasi ini disebabkan oleh beberapa penyebab yaitu:

1. Belum cukup dalam bersosialisasi

Masih belum optimalnya dalam mensosialisasikan PPDB, sehingga menjadi kendala saat pelaksanaannya. Sosialisasi diberikan kepada camat, lurah, kepala sekolah serta tokoh masyarakat yang berperan, namun ternyata belum cukup menjangkau orang tua. Beberapa sekolah yang mengutamakan sistem zonasi mendorong orang tua melakukan memanipulasi data jarak rumah dengan sekolah yang dipilih, memanfaatkan peluang untuk jual beli kursi sekolah favorit, dan menggunakan kepemilikan KIP dan KIS agar dapat diterima sekolah.

2. Kendala teknis

Permasalahan lain yaitu ada pada teknis terutama pada tahap seleksi daring karena disebabkan banyaknya calon peserta didik yang mengakses server PPDB sehingga terjadi gangguan. Pemerintah terlihat masih belum siap menghadapi segala masalah yang akan terjadi. Kurangnya sumber daya manusia sebagai operator dalam menangani masalah teknis PPDB dan tidak semua orang tua mengerti tentang teknologi sehingga tidak dapat memonitor perkembangan seleksi daring.

3. Kapasitas yang tidak mencukupi

Permasalahan utama dalam sistem zonasi adalah tidak seimbang antara kuota kursi sekolah yang disediakan dengan jumlah calon peserta didik. Data statistik pendidikan dasar 
dan menengah 2016/2017 tergambar bahwa semakin tinggi jenjang pendidikan, maka semakin sedikit jumlah peserta didik yang diterima. Ketidakseimbangan data statistik ini mengakibatkan kompetisi mendapatkan kursi di sekolah negeri menjadi lebih ketat dan tidak semua calon peserta didik mampu ditampung oleh sekolah yang terdekat dengan tempat tinggalnya.

4. Tingginya disparitas kualitas sekolah

Kenyataannya disparitas kualitas antar sekolah masih menjadi tugas rumah bagi Kemendikbud yang seharusnya dibenahi terlebih dahulu agar semua sekolah layak memberlakukan sistem zonasi.

\section{b. Kebijakan Sistem Zonasi}

Kebijakan pada Sistem Zonasi PPDB 2018/2019, Sistem zonasi PPDB menjadi kebijakan yang telah berlaku sejak tahun 2017, yang dimaksudkan untuk pemerataan kualitas pendidikan di Indonesia, dengan harapan dapat menghilangkan dikotomi sekolah unggulan dan non-unggulan. Perbedaan sistem zonasi tahun ini dengan tahun 2017, sistem zonasi tahun ini diberlakukan untuk seluruh sekolah yang diselenggarakan oleh pemerintah daerah. Sedangkan pada sistem zonasi PPDB 2017 masih tahap adaptasi sehingga dalam praktiknya belum seluruh sekolah menerapkan sistem zonasi (Setiyanti, 2019).

Menurut Permendikbud No. 14 Tahun 2018 ketentuan sistem zonasi adalah prioritas calon peserta didik (SMP dan SMA) yang wajib diterima meliputi: individu dengan jarak tempat tinggal ke sekolah sesuai ketentuan zonasi, Surat Keterangan Hasil Ujian Nasional (bagi lulusan SMP), memiliki prestasi akademik dan non-akademik. Sementara untuk jenjang SD, sistem zonasi menjadi pertimbangan kedua setelah faktor minimum usia masuk sekolah sudah terpenuhi. Semua sekolah yang diselenggarakan pemerintah daerah wajib menerima peserta didik baru yang tinggal di zona dekat dengan sekolah, minimal 90\% dari total jumlah peserta didik yang diterima. Sisanya $10 \%$ dari total jumlah peserta didik dibagi menjadi dua kriteria, yaitu 5\% untuk jalur prestasi di luar jarak terdekat dari sekolah, dan 5\% lagi untuk peserta didik yang mengalami perpindahan domisili atau terjadi bencana.

Azhari \& Suryanef (2019) mengatakan pemerintah daerah provinsi wajib menerima dan memberi kebebasan biaya pendidikan bagi peserta didik baru yang berasal dari ekonomi tidak mampu yang berdomisili dalam satu wilayah daerah provinsi. Jumlahnya paling sedikit $20 \%$ dari keseluruhan peserta didik yang diterima. Saat ini aturan pada sistem zonasi berlaku untuk 
semua daerah di Indonesia kecuali daerah tertentu yang secara geografis dan jumlah ketersediaan sekolah tidak memungkinkan untuk sistem ini. Daerah yang masuk kategori tersebut adalah daerah 3T (tertinggal, terdepan, dan terluar), sekolah khusus, sekolah milik swasta, dan sekolah bersama sesuai dengan ketentuan Pasal 29 Permendikbud No. 14 Tahun 2018 tentang PPDB.

\section{c. Pro Kontra Kebijakan Sistem Zonasi}

Penerapan kebijakan sistem zonasi dalam PPDB 2018/2019 mengakibatkan pro dan kontra masyarakat. Beberapa yang menjadi perdebatan antara lain: Pertama, memprioritaskan domisili calon peserta didik dengan sekolah sebagai penentu utama PPDB. Pihak yang kontra terhadap sistem zonasi menilai bahwa memprioritaskan domisili sebagai penentu utama PPDB masih sulit untuk diterapkan di berbagai Daerah, melihat jumlah lulusan sekolah dengan ketersediaan sekolah untuk semua daerah belum seimbang. Mengakibatkan ada beberapa sekolah yang menjadi kekurangan calon peserta didik, sementara ada sekolah yang jumlah pendaftarnya melebih kuota karena berada di zona padat penduduk. Kemendikbud berpegang pada prinsip pemerataan kualitas pendidikan, artinya anak-anak Indonesia mempunyai kesempatan yang sama untuk mengakses pendidikan yang bermutu.

Adanya sistem zonasi bertujuan untuk meratakan sekolah negeri supaya selanjutnya tidak ada sekolah dengan predikat unggulan dan non-unggulan. Selain itu dengan adanya sistem zonasi akan lebih mendekatkan anak dengan lingkungan keluarganya. Sistem zonasi memiliki dampak yang baik pada perkembangan anak. Menurut praktisi pendidikan, Arif Rahman mengatakan bahwa persoalan utama dalam menerapan sistem zonasi PPDB bukan jarak antara domisili peserta didik dengan sekolah tetapi lebih kepada pemerataan kualitas pendidikan di Indonesia (tirto.id, 13/7/2018).

Kedua, tujuan penerapan sistem zonasi PPDB. Perbedaan pemahaman terhadap aturan sistem zonasi PPDB akan akan memberikan dampak pada implementasi yang tidak sesuai dengan aturan yang ditetapkan. Di Yogyakarta, sistem zonasi PPDB SMP didasarkan pada jarak RW tempat tinggal calon peserta didik sesuai KK orang tua ke sekolah terdekat. Namun demikian, sistem ini tidak diterapkan secara penuh dengan tetap memberikan kuota untuk jalur prestasi bagi siswa dengan nilai tinggi (tirto.id, 9/7/2018). Sementara di Tangerang, sistem zonasi PPDB SMP didasarkan pada wilayah kelurahan sekolah tersebut (tangerangkota. go.id, 9/5/2018). Berbeda lagi di Lampung, selain jalur zonasi, PPDB SMA juga dapat melalui jalur 
mandiri dengan kuota 5\%. Peserta didik yang diterima melalui jalur mandiri wajib membayar sumbangan sekolah yang besarannya ditentukan oleh kebijakan sekolah (radartvnews.com, 26/2/2018). PPDB jalur mandiri ini meresahkan masyarakat, karena sekolah terkesan dapat dibeli oleh siswa dari keluarga mampu dan keluarga yang kurang mampu tidak bisa masuk ke sekolah tersebut. Apabila hal ini berlanjut, maka tujuan dari sistem zonasi untuk pemerataan pendidikan di Indonesia tidak akan bisa tercapai.

Ketiga, penggunaan Surat Keterangan Tidak Mampu (SKTM). Munculnya SKTM berawal dari ketentuan sistem zonasi PPDB dengan prioritas jarak yang mengakibatkan orang tua calon peserta didik terutama di luar zonasi akan mencari berbagai cara supaya anaknya bisa diterima di sekolah yang diinginkan. Jumlah kuota SKTM sebesar 5\% untuk jalur prestasi dinilai terlalu kecil bagi siswa dari luar zonasi, sedangkan belum semua sekolah memiliki fasilitas yang memadai. Akibatnya, kuota 20\% untuk keluarga tidak mampu dianggap sebagai peluang yang besar bagi orang tua. Jalur SKTM pun muncul dalam PPDB, Permendikbud No. 14 Tahun 2018 tentang PPDB tidak mengatur mengenai jalur SKTM dalam penerimaan peserta didik baru. Sedangkan pasal 19 Permendikbud No. 14 Tahun 2018 tentang PPDB hanya memberi kuota $20 \%$ untuk keluarga tidak mampu yang bertempat tinggal di wilayah daerah provinsi. Terkait hal ini, Komisioner Komisi Perlindungan Anak Indonesia mengungkapkan temuan berupa 78.065 SKTM palsu di Jawa Tengah. Penggunaan SKTM sebagai syarat siswa masuk kuota tidak mampu memang sangat rawan dimanipulasi (Republika, 14/7/2018: 4).

\section{d. Solusi Permasalahan Sistem Zonasi PPDB}

Sistem zonasi adalah salah satu cara pemerintah untuk memastikan proses pemerataan kualitas pendidikan berjalan dengan baik. Sistem zonasi diharapkan tidak ada lagi jual beli bangku sekolah dan harus dihilangkan. Selain itu, sistem zonasi akan mempermuda pemerintah untuk melakukan pemetaan anggaran pendidikan, populasi siswa, dan tenaga pendidik. Terkait pro kontra yang ada, solusi perbaikan yang disarankan ke depannya adalah:

Pertama, sebelum memberlakukan kebijakan, pemerintah perlu adanya persiapan matang. Sosialisasi sistem zonasi harus dilakukan secara terus-menerus dan dalam waktu yang panjang sebelum diterapkannya kebijakan tersebut, agar pemerintah daerah dan masyarakat dapat memahami kebijakan yang telah dibuat secara komprehensif. Sistem zonasi bukan hanya tentang jarak, namun lebih jauh lagi untuk mewujudkan pemerataan kualitas pendidikan di Indonesia. 
Kedua, mempertimbangkan ketersediaan jumlah sekolah di setiap zona. Saat ini jumlah sekolah negeri antara satu wilayah dengan lainnya belum merata. Ada satu zona yang terdapat banyak sekolah negeri, tetapi zona lain kekurangan sekolah negeri. Oleh karena itu, pemerintah harus mengevaluasi kembali proyeksi lulusan sekolah. Dari data ini akan terlihat perbandingan jumlah lulusan sekolah dan ketersediaan sekolah yang akan digunakan untuk menentukan zonasi. Apabila ditemukan jumlah lulusan sekolah lebih sedikit dibandingkan ketersediaan penerimaan, maka sebaiknya dilakukan pelebaran daerah zonasi. Dengan cara ini, calon peserta didik yang saat ini masih berada di area blank spot akan teratasi.

Ketiga, Kemendikbud dan Kemendagri perlu berkoordinasi dan memantapkan rencana sebelum menerapkan kebijakan baru pada sekolah-sekolah, sehingga permasalahan SKTM palsu dapat diantisipasi dan dapat dicegah adanya SKTM palsu. Penerbitan SKTM harus selektif mulai dari proses pembuatan SKTM yang transparan hingga verifikasi data calon peserta didik agar tidak salah gunakan, pemohon pembuatan SKTM harus benar-benar dari keluarga ekonomi tidak mampu dan hal itu harus di dukung dengan langsung melakukan survey lapangan. Sanksi yang akan diberikan bagi calon peserta didik yang menyalah gunakan SKTM juga perlu ditegakkan supaya tidak salah dalam menggunakannya.

Keempat, pandangan orang tua tentang sekolah unggulan harus mulai diubah dengan cara bersosialisasi, bahwa selanjutnya semua sekolah dengan predikat unggulan tidak ada lagi seiring diberlakukannya sistem zonasi PPDB. Terkait persepsi, Philip Kotler menjelaskan sebagai proses seseorang dalam menyeleksi, mengatur, dan menginteprestasikan masukanmasukan, informasi untuk menciptakan gambaran keseluruhan yang berarti (Kohler, 1993: 219). Proses terbentuknya persepsi dimulai dari kondisi sekolah yang belum merata dari segi kualitas dan kuantitas. Kondisi tersebut dapat diperkuat dari pengalaman orang tua lain yang telah mendaftarkan anaknya ke sekolah dengan predikat sekolah unggulan. Pada akhirnya, sehingga persepsi orang tua calon peserta didik tentang sekolah dengan predikat unggulan dan non-unggulan. Hal ini dapat mempengaruhi pola pikir orang tua dalam memilih sekolah untuk anaknya.

\section{METODE}

Penelitian dengan judul "Efek sosial psikologis sistem zonasi penerimaan peserta didik baru di SMK" penelitian ini menggunakan pendekatan kualitatif. Pendekatan kualitatif adalah metode penelitian yang dibentuk dari uraian kata-kata atau kalimat untuk dikumpulkan menjadi 
satu dan kemudian dilakukan analisis untuk mendapatkan bahan penulisan yang otentik. Pendekatan kualitatif merupakan suatu prosedur penelitian yang akan menghasilkan data deskriptif berupa kata-kata tertulis atau lisan dari orang-orang yang kita mintai data, penjelasan dan perilaku yang bisa untuk diamati (Moleong, 2006). Penelitian ini menggunakan tipe studi kasus, di mana peneliti bisa mendapatkan pemahaman utuh dan terintegrasi mengenai interelasi berbagai fakta-fakta dan dimensi dari sebuah kasus-kasus tersebut. Metode penelitian menggunakan penelitian kualitatif dengan metode wawancara secara mendalam dengan random sampling. Subyek penelitian meliputi guru, orang tua, siswa, stake holder salah satunya yaitu ketua RT setempat yang termasuk sistem zonasi. Dalam penelitian ini peneliti menggunakan studi kasus instrinsik, di mana penelitian ini dilakukan karena adanya ketertarikan atau kepedulian peneliti terhadap suatu kasus khusus. Peneliti dalam penelitian ini menggunakan studi kasus untuk memahami secara utuh kasus tentang efek sosial psikologis sistem zonasi dalam penerimaan peserta didik baru di SMK, penelitian ini dimaksudkan untuk menghasilkan konsep-konsep atau teori tanpa adanya upaya dalam menggeneralisasi (Poerwandari, 2011).

Penelitian ini akan menggunakan teknik wawancara dengan pedoman umum, di mana dalam proses wawancara, peneliti dibekali dengan panduan wawancara yang umum dilakukan dengan mencantumkan isu-isu yang harus digali tanpa menentukan urutan pertanyaan. Peneliti dalam penelitian ini menggunakan panduan wawancara karena untuk pengingat peneliti terhadap aspek-aspek yang akan dibahas dalam mengupas kasus tertentu, sekaligus menjadi daftar pengecek (checklist) aspek-aspek relevan tersebut telah dibahas atau ditanyakan pada subyek yang telah diwawancarai (Poerwandari, 2011). Peneliti juga menggunakan teknik wawancara bebas, di mana peneliti bebas menanyakan apa saja yang membantu dalam mencari info, akan tetapi sebagai pengingat akan data apa yang akan dikumpulkan oleh peneliti (Arikunto, 2005). Peneliti dalam penelitian ini akan menggunakan wawancara bebas karena peneliti dapat mengantisipasi apabila akan terjadi ada jawaban yang kurang sesuai dengan pertanyaan yang ditanyakan oleh peneliti dari subjek sehingga dapat menggali jawaban tersebut sampai menemukan informasi yang jelas pada sebuah kasus yang ingin diungkapkan atau dibuktikan.

Penelitian ini dalam pengumpulan data atau pengambilan subjek menggunakan Purposive Sampling karena fenomena dalam penelitian ini subjek harus sesuai dengan tema/judul yang akan dibahas tentang pendapat setiap subjek yang mengalami sistem zonasi 
baik itu dari siswa, orang tua, guru maupun tokoh masyarakat karena peneliti ingin mendapatkan data dari setiap pendapat tentang efek sosial adanya sistem zonasi dalam penerimaan peserta didik baru (PPDB).

a. Teknik Analisis Data Penelitian

Peneliti dalam penelitian ini akan menggunakan teknik analisiis kualitatif yaitu studi kasus. Studi kasus ialah bertujuan untuk mempelajari dan menyelidiki suatu kejadian atau fenomena yang diteliti. Dengan menggunakan analisis tersebut bisa mendapatkan apa yang ingin diteliti dan akan mengungkapkan hasil dari penelitian tersebut.

b. Lokasi Penelitian

Lokasi penelitian dilakukan di salah satu sekolah yang berada di Surabaya pada beberapa siswa dan orangtua siswa ketika mengantarkan anaknya untuk mendaftar ke sekolahan yang diinginkan. Untuk tokoh masyarakat peneliti mewawancarai subjek yang berada dekat rumah peneliti dan untuk guru, peneliti mewawancarai teman peneliti di tempat kerja.

c. Subjek Penelitian

Subjek dalam penelitian ini menggunakan siswa yang mendaftar ke sekolah dengan sistem zonasi baik siswa SMA maupun siswa SMK, kepada orang tua, kepada guru dan yang terakhir kepada tokoh masyarakat. Diambil dengan cara Purposive Sampling dengan kriteria Siswa yang akan masuk sekolah SMK, orang tua yang memiliki anak yang akan masuk sekolah SMK, guru SMK yang terdapat sistem zonasi di tempat mengajar. Pengambilan data tersebut didasari perlunya pengungkapan informasi secara mendalam sehingga tidak menghambat proses pengambilan keputusan terjadi.

\section{HASIL DAN PEMBAHASAN}

1. Analisis Subjek Pertama

Subjek pertama yang diwawancarai oleh peneliti yaitu orang tua dari salah satu siswa yang akan memasuki dunia pendidikan pada jenjang SMK. Hasil wawancara menunjukkan bahwa subjek pertama menunjukkan reaksi yang tidak setuju dengan adanya sistem zonasi saat penerimaan peserta didik baru (PPDB). Subjek pertama mengatakan bahwa sistem zonasi tidak bermanfaat dan merugikan bagi siswa. Hal ini dikarenakan karena siswa yang diterima sebagian besar berada di dekat dengan lokasi tempat tinggal siswa. Di sisi lain, siswa tidak menginginkan sekolah di dekat lokasi tempat tinggalnya. Hal ini dikarenakan siswa tidak bisa 
memilih sekolah favorit yang diinginkan. Akan tetapi banyak anak pula yang menginginkan sekolah jauh dari lokasi tempat tinggal. Hal ini dikarenakan siswa menginginkan sekolah favorit yang ada di tempat tersebut. Hal semacam ini, akan menimbulkan efek sosial psikologi seorang anak karena merasa tertekan tidak dapat masuk ke sekolahan yang diinginkan, akan merasa tertekan karena anak tidak sepenuh hati dalam belajar di sekolah yang tidak diinginkan, anak juga bisa menjadi pendiam karena tidak ada pilihan lain bagi siswa yang jauh dari sekolahsekolah favorit. Anak sudah terlanjur melakukan bimbingan belajar dan les privat untuk mengejar sekolah favorit yang diinginkan. Di sisi lain, ada pula orang tua yang menyetujui sistem zonasi. Hal ini dikarenakan siswa supaya lebih dekat dengan rumah dan tidak menghabiskan waktu di jalan. Selain itu orang tua bisa aktif memantau segala kegiatan dan aktivitas yang dilakukan anak di sekolah.

\section{Analisis Subjek Kedua}

Subjek ke dua dalam penelitian ini yaitu guru dari salah satu sekolah yang menjadi favorit di kalangan siswa SMK. Hasil wawancara menunjukkan bahwa guru sangat setuju dengan program zonasi. Dengan adanya sistem zonasi dalam penerimaan peserta didik baru (PPDB) membuat tidak adanya perbedaan sekolah yang menjadi favorit dan tidak favorit, dalam hal ini semua sekolah mempunyai nilai yang sama sehingga tidak adanya kecemburuan sosial yang mengakibatkan munculnya sekolah favorit dan tidak favorit. Di sisi lain zonasi sangat efektif bagi siswa karena siswa dapat bersekolah dengan tempat yang terdekat dengan tempat tinggalnya. Namun ada juga guru yang tidak setuju akan adanya sistem zonasi dalam penerimaan peserta didik baru, karena tidak bisa memberikan peluang yang sama untuk bisa masuk ke sekolah yang diinginkan. Dengan adanya sistem zonasi ini akan memberikan dampak atau efek bagi sosial psikologisnya seorang anak atau siswa oleh karena itu pemerintah harus terus mengevaluasi sistem penerimaan mahasiswa baru yang lebih efektif dan memiliki efek yang sedikit pula.

\section{Analisis Subjek Ketiga}

Selanjutnya peneliti mewawancarai salah satu siswa yang baru lulus SMP dan akan melanjutkan ke jenjang SMK. Subjek penelitian ini mengatakan lebih senang dan setuju dengan adanya sistem zonasi karena mendatangkan manfaat yang besar. Hal ini dikarenakan subyek memiliki keleluasaan dalam memilih sekolah yang terdekat. Selain itu subjek diuntungkan 
dengan adanya sistem zonasi karena bisa menjangkau sekolah dengan cepat tanpa perlu macet saat pergi ke sekolah serta tidak mengalami keterlambatan. Sedangkan beberapa siswa tidak menyetujui adanya sistem zonasi. Hal ini dikarenakan subyek mereka merasa dirugikan berupa mereka tidak bisa memilih sekolah favorit serta dapat menimbulkan efek psikologis pada setiap siswa karena merasa tidak cocok dengan sekolah yang dipilih serta bukan dari keinginan mereka melainkan karena tuntutan yang sudah ditetapkan oleh pemerintah.

\section{Analisis Subjek Keempat}

Subjek ke empat yaitu tokoh masyarakat (Ketua RT tempat tinggal subjek) sangat mendukung adanya sistem zonasi dalam penerimaan peserta didik baru karena bisa siswa yang bertempat tinggal di sekitar lingkungan setempat mampu bersekolah di sekolah yang terdekat. Dengan adanya sistem seperti itu orangtua akan memiliki waktu lebih banyak untuk memantau anak-anak ketika di sekolah dan ketika di lingkungan keluarga. Dengan adanya sistem zonasi bisa membagi antara sekolah-sekolah yang berada di setiap kota dan harus dibatasi ketika menerima peserta didik baru.

Berdasarkan hasil wawancara dengan keempat subjek diperoleh hasil yang menunjukkan bahwa pada subyek pertama berpendapat bahwa Subjek pertama mengatakan bahwa sistem zonasi tidak bermanfaat dan merugikan bagi siswa. Hal ini dikarenakan karena siswa yang diterima sebagian besar berada di dekat dengan lokasi tempat tinggal siswa dan akan mengakibatkan dampak psikologis bagi siswa seperti merasa tertekan, tidak bersemangat, tidak adanya daya Tarik untuk tetap belajar, dan masih banyak lagi dampak psikologis untuk siswa. Subyek kedua menunjukkan bahwa siswa tidak setuju dengan progam zonasi karena tidak bisa maksimal dalam belajar, tidak adanya semangat yang tinggi karena tidak bisa sekolah sesuai dengan keinginan, menyebabkan kemalasan, dan kurangnya ketertarikan terhadap sekolah maupun belajar. Subyek ketiga Subjek penelitian ini mengatakan lebih senang dan setujuh dengan adanya sistem zonasi karena mendatangkan manfaat yang besar seperti pemerataan dalam hal ekonomi dan akan merasakan sama rata tanpa membeda bedakan kalangan atas bawah dan menengah sehingga tidak berdampak psikologis pada orang tua, guru maupun siswa. Hal ini dikarenakan subyek memiliki keleluasaan dalam memilih sekolah yang terdekat. Selain itu subjek diuntungkan dengan adanya sistem zonasi karena bisa menjangkau sekolah dengan cepat tanpa perlu macet saat pergi ke sekolah. 
Dengan adanya sistem zonasi dalam penerimaan peserta didik baru (PPDB) membuat tidak adanya perbedaan sekolah yang menjadi favorit dan tidak favorit dan dampak pada psikologis siswa akan lebih bersemangat dalam belajar, bisa fokus karena tidak merasa capek akibat jarak yang ditempuh rumah ke sekolah. Subjek ke empat yaitu tokoh masyarakat (Ketua RT tempat tinggal subjek) sangat mendukung adanya sistem zonasi dalam penerimaan peserta didik baru karena bisa siswa yang bertempat tinggal di sekitar lingkungan setempat mampu bersekolah di sekolah yang terdekat dan orang tua tidak khawatir karena jarak antara sekolah dan rumah dekat, bisa di tempuh dengan waktu yang singkat.

Tabel Data Informan Sistem Zonasi

\begin{tabular}{ll}
\hline Informan Pertama & Informan Ke Tiga \\
\hline Nama : IP & Nama : MR \\
Jenis Kelamin : Perempuan & Jenis Kelamin : Laki-laki \\
Usia : 45 Tahun & Usia : 15 Tahun \\
Alamat : Surabaya & Alamat : Surabaya \\
Pekerjaan : Ibu Rumah Tangga & Pekerjaan : Siswa \\
& \\
\hline Informan Ke dua & Informan Ke Empat \\
\hline Nama : PB & Nama : MH \\
Jenis Kelamin : Laki-laki & Jenis Kelamin : Laki-laki \\
Usia : 26 Tahun & Usia : 48 Tahun \\
Alamat : Surabaya & Alamat : Surabaya \\
Pekerjaan : Guru Olahraga & Pekerjaan : Ketua RT \\
\end{tabular}

\section{SIMPULAN}

Hasil penelitian yang sudah diperoleh dapat disimpulkan bahwa terdapat sebagian orang yang setuju dengan adanya sistem zonasi karena dengan adanya sistem zonasi bisa membuat sekolah menjadi sama rata, membangun strategi pengelolaan pendidikan yang berkesinambungan pada setiap jenjang pendidikan namun ada juga sebagian orang yang merasa bahwa dengan adanya sistem zonasi penerimaan peserta didik baru tidak efektif karena terlalu membatasi siswa untuk masuk ke sekolah yang diinginkan dan membuat anak tidak maksimal dalam mengembangkan diri karena tidak masuk dalam sekolah yang di inginkan karena terhalang oleh jarak serta menurunkan motivasi belajar siswa, akan menjadikan siswa tertekan, tidak bersemangat. Oleh karena itu kementrian pendidikan harus mengevaluasi lebih lanjut 
terkait dengan sistem penerimaan mahasiswa baru (PPDB) agar bisa menjadi lebih efektif lagi dan tidak menimbulkan efek bagi orang tua, guru, siswa dan seluruh warga Negara.

\section{DAFTAR PUSTAKA}

Ahsan Ridhoni. (2017). Pro kontra sistem zonasi dalam penerimaan peserta didik baru.Tirto.

ID. https://tirto.id/pro-kontra-sistem-zonasi-dalam-penerimaan-siswa-baru-csEh

Andina, E. (2017). Sistem zonasi dan dampak psikologi bagi peserta didik. Pusat Penelitian Badan Keahlian DPR RI.

Arikunto, Suharsimi. (2005). Research Procedure A Practical Approach. Rineka Cipta.

Dewi, K. E., \& Sptiana, R. (2018). Evaluation of the zoning student recruitment system in year 2018. Proceeding international seminar on education innovation issues and challenges in education for education sustainability sarjanawiyata University Tamansiswa. (August), 109-115.

Hudin, J. M., Farlina, Y., Saputra, R. A., Gunawan, A., Pribadi, D., \& Riana, D. (2019). Measuring quality of information systems through the delone mclean model in the online information system of new student registration (SISFO PPDB). 2018 6th International Conference on Cyberand IT Service Management, CITSM 2018, (Citsm), 1-6. https://doi.org/10.1109/CITSM.2018.8674310

Kemendikbud: SKTM Regional Affairs, Republika, access 14 Juli 2019. Institute for Development of Educational Facilities and Psychology Education (LPSP3) UI.

Moleong, J. (2006). Qualitative research methods. PT. Remaja Rosdakarya.

Nurlailiyah, A. (2003). Analysis of zoning system policies on junior high school student behavior in Yogyakarta. Realita: Jurnal Penelitian dan Kebudayaan Islam, 17(1), 1322.

Põder, K., Lauri, T., \& Veski, A. (2017). Does school admission by zoning affect educational inequality? a study of family background effects in Estonia, Finland and Sweden. Scandinavian Journal of Educational Research, 61 (6), 668-688. https://doi.org/10.1080/00313831.2016.1173094

Poerwandari. (2011). Qualitative approach to research in human behavior. PT. Remaja Rosdakarya. 
Purwanti, D., Irawati, I., Adiwisastra, J., \& Bekti, H. (2019). Implementation of new student admission policies based on zoning systems in the city of Bandung. Governansi Journal, 5 (1), 12. https://doi.org/10.30997/jgs.v5i1.1699

PPDB. (2019, 5 Juli). Use the village zoning system. PPDB. https://tangerangkota. go.id/ppdb2018-use-systemzonasi-kelurahan

PPDB. (2019, 5 Juli). Independent track, disdikbud Lampung prepare 5 percent quota. Radar TV News. http://www.radartvnews.com/ppdb-mandiri-disdikbudlampung-preparequota-5-percent /.

Setiyanti, H. (2019). Using zone systems in equalization and improving education quality (case study in temanggung sub-private vocational school). Post Graduate Program University of Muhammadiyah Yogyakarta.

Sularto, S., Wahyudi, W., \& Sukmawati, S. (2018). The admission of new students based on the online system at SMAN 2 Singkawang. JETL (Journal of Education, Teaching and Learning), 3 (2), 336. https://doi.org/10.26737/jetl.v3i2.772

Wardhana, L. P., Supriyoko, K., \& Magelang, K. (2019). Management of new student admissions online on the basis of zoning, Achievements and Introduction. Media Manajemen Pendidikan, 2(2), 228-235.

Wulan, B. A., Soedijono, B., \& Henderi. (2017). Evaluation of bio system online acceptance using the technology acceptance model (TAM) approach. Journal of Information Technology, 12(2), 26-35.

Wulandari, D., Hasyim, A., \& Nurmalisa, Y. (2018). Pengaruh penerimaan peserta didik baru melalui sistem zonasi terhadap prestasi belajar siswa. Jurnal Kultur Demokrasi, 5(9), $1-15$. 